\title{
The Use of Bilingual Methods through Scientific Approach at Integrated Subject to Improve the Student's English Skills
}

\author{
Cholifah Tur Rosidah ${ }^{1, *}$, Suryaman $^{2}$ \\ ${ }^{1}$ Teacher and Education Science, Primary Teacher Education Program, PGRI Adi Buana University of Surabaya, Indonesia \\ ${ }^{2}$ Post-Graduate Study, Educational Technology Program, PGRI Adi Buana University of Surabaya, Indonesia
}

\begin{abstract}
This study was aimed to know the PGRI Adi Buana Surabaya primary teacher education program student's English skill after being applied through scientific approach at integrated subject. Therefore, this study was conducted to support the student's readiness in facing globalization era and international challenge, also created competent, superior, and high character. This study was an action research which conducted in two cycles. There were four steps namely planning, action, observation or evaluation and reflection. The subject of this study was 40 students of $\mathrm{C}$ class 2015. The data obtained was analyzed through descriptive analytic static. The result showed that there was 32, 74\% enhancement of the student's English skills after applied bilingual method through scientific approach. That enhancement could be seen on the average result of the cycle I which showed $47,58 \%$ as a low category and increased to $80,32 \%$ at cycle II as good category.
\end{abstract}

Keywords: Bilingual method, scientific approach, English skills

\section{Introduction}

Teaching learning process is meant to build the student's knowledge, attitudes, and skills. By having those three elements, they are intended to be able facing global challenge. The global challenge itself couldn't be avoided especially when WCU (World Class University) comes. As cited by www.antaranews.com in 2007, The Minister of National Education at that time, Prof. Dr. Bambang Sudibyo, MBA was preparing 50 universities for WCU. Since then, both state and private universities has competed in preparing great skilled graduates in their fields and also in international arena.

Educational institutions especially universities are required to preparing the student's skill in facing the globalization such as developing the science and language fields. Foreign language proficiency must be applied in order to improve the education quality. By doing so, English subject must be put on the requirement of graduation. However, the students of PGSD Unipa only get once English subject for eight semesters. As a result, it hasn't given a great result yet. This problem can be solved by applying bilingual program for all subjects; one of them is integrated learning course.

Literally, bilingualism is also called as two languages (KBBI: 2016). According to that literary meaning, it can be drawn that bilingualism is related to the use of two languages or two language codes. Sociolinguistically in general, bilingualism can be interpreted as the use of two languages by a speaker in association with others. Therefore, Bilingual method is a method of learning by using a language other than mother tongue (Chreese: 2010). In this study, the writer both uses Indonesian and English language. The result of the previous study on bilingual methods can be several reasons why bilingual methods are important to apply in a lesson. As presented by Turnbull (2016) which concludes that bilingual model learning may be applied to train foreign language abilities of children other than the original language. But, in the learning process, bilingual methods become less effective if only done by the teacher, so it is also required the active participation of students. Herdia (2016) explains on his research that the application of bilingual methods is a challenging learning in any country, in addition to preparing students in global challenges also requires the ability of teachers who master foreign languages.

\footnotetext{
rosidahcholifah@gmail.com
} 
To support the application of bilingual methods in order to run effectively and obtain optimal results, it can be supported by a scientific approach that centralizes learning to students. The scientific approach is a learning approach designed in such a way that learners actively construct concepts, laws, or principles through the stages of observing, questioning, gathering information, associating, and communicating (Wieman: 2010).

From some research results indicated that the lecturer is obliged to equip his students with other skills, such as proficiency in language to compete in the international world. Based on this study, the application of bilingual method should be done by using a scientific approach that centralizes learning to students so as to optimize students' English skills.

\section{Methods}

Research method is a tool, procedure and technique selected in conducting research (Djajasudarma: 2010). The research approach is concerned with some analysis steps in processing scientific information. It is the basic concept used as the framework of thinking in a study. This research includes a classroom action research, a reflective form of research based on specific actions to improve the competence of learning process in classroom (Agung: 2012). This research was conducted during the process of integrated learning and lecturing on the students of primary teacher education program at C class 2015 at PGRI University Adi Buana Surabaya.

There are some steps in conducting this study, namely planning, acting, observing, and reflecting. At the planning step, the researcher prepares teaching materials, design of the action in form of a lesson plan, an evaluation plan that includes assignment and performance, and the media to be used in teaching learning process.

At the acting stage, implementation is done in accordance with the prepared planning. During lecturing process, lecturers will deliver integrated learning materials through bilingual method by using scientific approach. The lecture process is packed by prioritizing student activities in observing, questioning, gathering information, reasoning, and communicating in 2 languages, Indonesian and English. Furthermore, at the observing step, observation is conducted during the learning process. Taking observation data aims to observe directly the behavior of students, especially speaking, listening, writing and reading skills. The reflecting step will be done to examine the results of actions in cycle I which relates to bilingual method through scientific approach. The results of this study then will be used to look for and set some alternative and new effective action to be made as an action research cycle II. The cycle can be seen in chart 1 below.

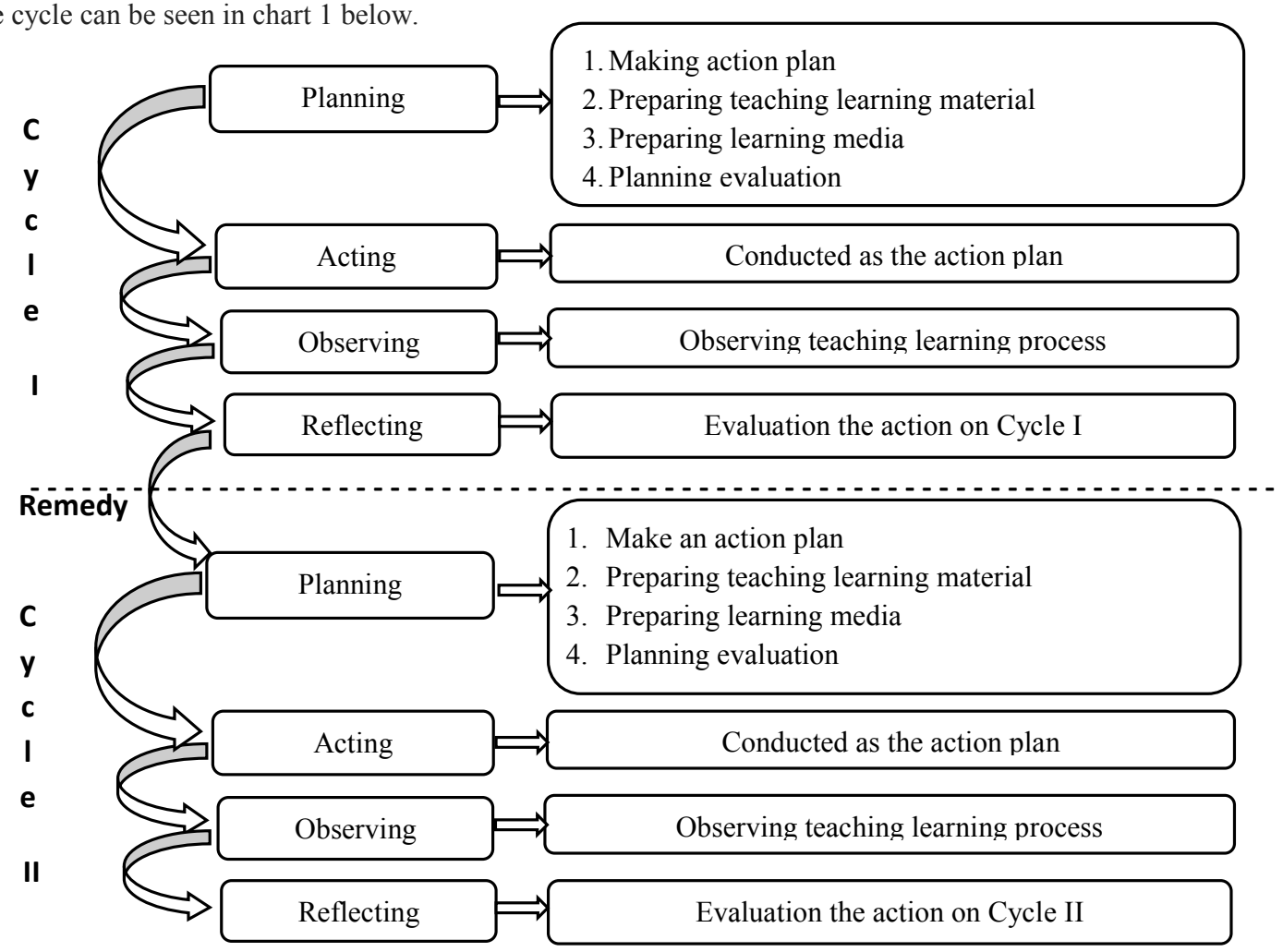

Figure. 1 Research cycle 
The cycle model used in the study refers to the model developed by Arikunto (2014) which mentions the class action consisting of four stages: planning, acting, observing, and reflecting. The methods used to collect data are observation, documentation, and tests. Observations are made using an observation sheet during the learning process. Documentation includes all recording materials and photographs during the study. Tests conducted in research in the form of oral and written tests to determine the level of English language skills students' development.

Data analysis of this study used descriptive statistical analysis and quantitative descriptive. Agung (2012), descriptive statistic analysis method is a way of data management by applying descriptive statistic techniques and formulas such as frequency distribution, graph, mean number (mean, median, mode) to describe the state of an object to obtain general conclusion. While the method of quantitative descriptive analysis is used to determine the students' speaking abilities that are converted in the assessment of the five-point benchmark (PAP).

\section{Results and Discussions}

Here are the results of the study applied to the primary teacher education program students of PGRI Adi Buana Surabaya C Class 2015 which held in 2 cycles starting on March, 08 to July, 21, 2017. Cycle I consisted eight meetings which starts from March 8, 2017 to April 25, 2017. Seven times meetings used for teaching learning, and the rest were used for evaluation at the end of the cycle. Furthermore, cycle II also consisted of eight meetings. Teaching learning process was held during seven meeting and the last meeting was used as the final evaluation. The evaluation was done starting on May 12, to July 21, 2017. The description of statistical analysis result is presented in Table 1.

\begin{tabular}{|c|c|c|}
\hline Statistik & Cycle I & Cycle II \\
\hline Mean & 5,15 & 8,05 \\
\hline Median & 8 & 15 \\
\hline Modus & 10 & 15 \\
\hline M \% & $47,58 \%$ & $80,32 \%$ \\
\hline
\end{tabular}

Table 1. Statistical Analysis Result

Based on the result of descriptive statistic analysis of cycle I, the mean was 5,15 . While the median showed the $50 \%$ upper limit and upper $50 \%$ frequency which containing the cumulative frequency of $1 / 2 \mathrm{~N}$ was 8.00 and the visible mode of the score indicating the highest frequency in cycle I was 10.00.

Based on the calculation of polygon graphs can be known M, Md, Mo indicated Mo $>\mathrm{Md}>\mathrm{M}(10.00>8.00>$ 5.15), so it can be concluded that the distribution of English language proficiency data on the first cycle was a negative crossover curve and most scores were low. Furthermore, to determine the level of students' English proficiency can be seen from the percentage ratio (M\%) with the five-level PAP criteria obtained by M $\% 47.58 \%$, which converted into five-level PAP is at 0-50\% mastery level which means that Level of students' English proficiency in cycle I on low criteria. Then this action research class needs to be continued into cycle II for further improvement and refinement.

Furthermore, descriptive analysis of cycle II obtained the mean of 8.05 while median was 15 and mode was 15. This means M, Md, Mo seen Mo> M (15.00> 8.05), so it can be concluded that the distribution of English language ability data in cycle II was a negative crossover curve and score Obtained tend to be high. The level of English language ability can be seen from the average percent (M\%) with the five-point PAP criterion that shows the number $80.32 \%$. After converted into five-level PAP shows the level of students 'English proficiency reaches 70 $85 \%$ which means that the level of students' English proficiency in cycle II was in good criteria. This shows an enhancement in the average percentage of the development of students' English skills from cycle I to cycle II of $32.74 \%$.

From the observation result, we know that bilingual method with scientific approach can make the learning process become more varied, interactive, and fun. Bilingual method with scientific approach done in practicing the language skills, among others, 1) listening skill, by giving questions based on material exposure; 2) reading skills, students read materials related to integrated learning courses using various English literature; 3) speaking skills, exposing or presenting the material of integrated learning course using English language; 4) writing skills, making an English resume at the end of each lecture. Based on the above description it appears that bilingual method with scientific approach in integrated learning course has tried to provide one of the services to students by using more varied learning method which oriented to the learners.

From the data obtained based on the results of evaluation and observation, it was known that there was a very significant increase in the ability of English speaking students from cycle I and cycle II. The application of bilingual 
method with scientific approach can give a good influence on the students' English skills. The success in this research showed that the application of bilingual method with scientific approach to improve the English language ability was very effective. To achieve optimal capability hence required also optimal learning process. The optimal learning process was not only a lecturer's job, but also the active participation of students. In addition the availability of facilities and infrastructure were also being a supporter in the success of learning. Based on the results and the description above, application of bilingual method with scientific approach in the integrated learning course can improve student's skill of PGRI University of primary teacher educational program.

\section{Conclusion}

Based on the result of data analysis, it can be concluded that after implemented the application of bilingual method with scientific approach in integrated learning course, there was improvement of English language skill of PGSD student of class $2015 \mathrm{C}$ equal to $32,74 \%$. The enhancement was seen from the average increase and the percentage of students' English proficiency in the first cycle of $47.58 \%$ to $80.32 \%$ in cycle II. Thus the application of bilingual method with scientific approach in integrated learning course can improve the English speaking skill of elementary school teacher education program at PGRI Adi Buana Surabaya.

Based on these conclusions, the following suggestions may be proposed: 1) for lecturers, it is advisable to increase creativity and ability in selecting and developing more innovative learning methods and in accordance with the needs of students, 2) for researchers, it is advisable to make further research as a refinement From bilingual method with scientific approach in improving students' English proficiency.

\section{Acknowledgements}

Education running dynamic followed the development of the world globally. Therefore we must also prepare our students to become part of globalization. One of them with unprepared to have English language skills with use of bilingual methods through scientific approach in learning process.

\section{References}

1. A. Creese, A. Blackledge. MLJ, 94, 103 (2010)

2. Agung, Iskandar. (2012). Panduan Penelitian Tindakan Kelas Bagi Guru. Jakarta: Bestari Buana Murni.

3. Anderson, L.W., Karthwohl, D.R. (2010). A Taxonomy for Learning, Teaching, and Asessing. New York: Addison Wesley Longman.

4. Araromi, Akinsola. JLLL, 13 (2015)

5. Arikunto, Suharsimi. 2014. Penelitian Tindakan Kelas. Jakarta: PT Bumi Aksara.

6. Bambang. 2007. 50 Universitas Disiapkan Jadi Wordl Class University. http://www.antaranews.com/berita/76042/50-universitas-disiapkan-jadi-world-class-university. Downloaded at January $10^{\text {th }} 2017$.

7. B. Turnbull. IJBEB, 1-8 (2016)

8. C. Wieman. Change, 39, 9-15 (2010)

9. Djajasudarma. (2010). Metode Linguistik: Rancangan Metode Penelitian dan Kajian. Bandung: Reflika Aditama.

10. Heong, et al. Procedia, 59, 197-203 (2012)

11. Kamus Besar Bahasa Indonesia (KBBI) Luar Jaringan (offline), Pusat Bahasa Kementrian Pendidikan Nasional (2016).

12. Limbach, Waugh. Instructional Pedagogies, 3, 1-9 (2010)

13. R.R. Herdia, J. Altarriba, A.B. Cieslicka. MBRCR, 18, 383-395 (2016)

14. Turiman, et al. Procedia, 59, 110-116 (2012) 